\title{
Failure of folic acid to influence mortality of rats with acute tubular necrosis caused by mercury
}

\author{
$\begin{array}{ll}\text { I. TARABA* } & \text { G. M. Bull } \dagger\end{array}$ \\ Department of Medicine, Queen's University, Belfast
}

ONE of the hypotheses advanced to explain the anuria or oliguria of acute tubular necrosis is that the glomerular filtrate is passively reabsorbed through the tubules which have been stripped of epithelium. Moreover, it has been suggested that the rise in urine volume in the early diuretic phase results from a relining of the tubules by division of surviving cells (Oliver, 1954). This process is well demonstrated in mercury poisoning. Noltenius, Schellhas \& Cehlert (1963), using radioactive thymidine to mark the synthesis of new DNA, found that the regeneration commenced after a latent period of $72 \mathrm{hr}$ from the mercury poisoning and spread upwards from the lowest end of the proximal convoluted tubule.

If this hypothesis to explain the anuria or oliguria is correct and if one could hasten the process of relining of the tubules, one might shorten the period of oliguria and improve the prognosis in mercury poisoning and in other varieties of acute tubular necrosis.

In this connection the work of Haddow (1954) and Taylor, Threlfall \& Buck (1966) is of special interest. Certain pteridines such as folic acid given intravenously to rats causes a marked and rapid increase in kidney weight. This increase in weight is associated with an outburst of mitotic activity and an increase of cell numbers. It therefore seemed worth while to test the effect of folic acid on the speed of regeneration of tubules in animals suffering from acute tubular necrosis induced by mercury and on their survival.

\section{Methods}

Rats of both sexes and weighing between 180 and $230 \mathrm{~g}$ were used. These were divided into the following five groups:

1. Five untreated animals.

* Present address: Institute of Physiology, University, Budapest.

$\dagger$ Present address: M.R.C., 164 Tottenham Court Road, London, W.1.
2. Five animals received $25 \mathrm{mg}$ folic acid/ $100 \mathrm{~g}$ body weight intravenously dissolved in isotonic $\mathrm{NaHCO}_{3}$ solution.

3. Twenty-five animals received intraperitoneally $0.25 \mathrm{ml} / 100 \mathrm{~g}$ body weight of an $0.1 \%$ solution of $\mathrm{HgCl}_{2}$.

4. Fourteen animals received the same dose of mercury as in (3) and either 24 or $48 \mathrm{hr}$ later an intravenous injection of isotonic dextrose.

5. Eight animals received the same dose of mercury as in (3) and $24 \mathrm{hr}$ later an intravenous injection of an isotonic solution of $\mathrm{NaHCO}_{3}$.

6. Twenty-seven animals received the same dose of mercury as in (3) and either 24 or 48 hr later received the same dose of folic acid intravenously as in (2).

The kidneys of all animals were collected as soon after death as possible, weighed and examined histologically. (Animals surviving after mercury poisoning were killed on the 14 th day.)

\section{Results}

Five animals in group 2 which received folic acid alone were killed $48 \mathrm{hr}$ after the injection. The results are shown in Table 1 compared with group 1.

TABLE 1

Effect of folic acid injection on kidney weight in normal rats

\begin{tabular}{lcc}
\hline & $\begin{array}{c}\text { Control } \\
(\mathrm{g})\end{array}$ & $\begin{array}{c}\text { F.A. treated } \\
(\mathrm{g})\end{array}$ \\
\hline & 1.240 & $2 \cdot 279$ \\
1.307 & 2.496 \\
1.477 & 2.490 \\
& 1.186 & 2.064 \\
Mean weight & 1.230 & 2.027 \\
SD & 1.394 & 2.276 \\
& \pm 0.226 & \pm 0.218 \\
\hline
\end{tabular}

The kidney weights and the histological examination confirm the findings of Taylor et al. 
(1966) of a marked increase in kidney weight and an increase in mitoses of tubular cells.

The mortalities in the animals receiving $\mathrm{HgCl}_{2}$ are shown in Table 2.

TABLE 2

$\mathrm{HgCl}_{2}$ injected animals

\begin{tabular}{|c|c|c|c|c|c|c|}
\hline & \multicolumn{3}{|c|}{ Folic acid treated groups } & \multicolumn{3}{|c|}{$\begin{array}{c}\text { Control groups } \\
\text { given dextrose or } \mathrm{NaHCO}_{2}\end{array}$} \\
\hline & $\begin{array}{l}\text { No. of } \\
\text { animals }\end{array}$ & Survived & Died & $\begin{array}{l}\text { No. of } \\
\text { animals }\end{array}$ & Survived & Died \\
\hline I & 8 & 4 & 4 & 4 & 2 & 2 \\
\hline II & 9 & 4 & 5 & 10 & 5 & 5 \\
\hline III & 10 & 2 & 8 & 8 & 4 & 4 \\
\hline
\end{tabular}

I. F.A. or dextrose injected $48 \mathrm{hr}$ after $\mathrm{HgCl}_{2}$ poisoning.

II. F.A. or dextrose injected $24 \mathrm{hr}$ after $\mathrm{HgCl}_{2}$ poisoning.

III. F.A. or $\mathrm{NaHCO}_{3}$ injected $24 \mathrm{hr}$ after $\mathrm{HgCl}_{2}$ poisoning.

On summed figures for Control and Treated Groups

$$
\begin{gathered}
x^{2}=0.39 \text { for } 1 \text { d.f. } \\
0.7>P>0.5 .
\end{gathered}
$$

It will be seen that approximately $50 \%$ of animals died and that there was no significant difference between those receiving folic acid and a control solution of either dextrose or $\mathrm{NaHCO}_{3}$.

The kidney weights of animals examined are shown in Table 3. (The numbers of animals dying on days other than the fourth were so small as to make comparison of kidney weights difficult. Therefore weights derived from deaths on day 4 only are shown in the table.)

Although the mean weights of the kidneys of animals receiving folic acid and mercury were greater than those receiving a control solution and mercury, the differences were not significant.
Moreover, histological examination did not reveal any difference between these groups in respect of mitotic activity or appearance of the tubule cells.

TABLE 3

Mean kidney weights of rats $(\mathrm{g})$

\begin{tabular}{llll}
\hline & & $\begin{array}{c}\text { Died on } \\
\text { 4th day }\end{array}$ & $\begin{array}{c}\text { Survived } \\
\text { 14 days }\end{array}$ \\
\hline $\begin{array}{l}\text { Non-treated normal kidney } \\
\text { Folic acid injected kidney }\end{array}$ & $\mathbf{1 . 3 0 1}$ & & \\
$\begin{array}{l}\mathrm{HgCl}_{2} \text { poisoned kidney } \\
\mathrm{HgCl}_{2} \text { poisoned + folic acid }\end{array}$ & 2.361 & 1.861 \\
$\quad$ treated kidney & 2.915 & 2.004 \\
\hline
\end{tabular}

\section{Discussion}

This study confirms the findings of Taylor et al. (1966) and Haddow (1954) that folic acid causes an increase in kidney weight and a multiplication of tubule cells in normal animals. However, when it was administered to rats poisoned with mercury, no such effect could be demonstrated and, moreover, the survival of animals so treated was unaffected.

\section{References}

Haddow, A. (1954) Chemistry and Biology of Pteridines: Ciba Foundation Symposium, p. 100. Churchill, London.

Noltenius, H., Schellhas, H. \& Oehlert, W. (1963) Histoautoradiographische Untersuchungen mit ${ }^{3} \mathrm{H}-\mathrm{Thy}-$ midin der Tubuluszellregeneration nach akuter Sublimatvergiftung von Ratten. Beitr. path. Anat. 129, 90.

OLIVER, J. (1954) The structural and functional aspects of recovery from acute renal failure. The Kidney: Ciba Foundation Symposium, pp. 1-14. Churchill, London.

TAYlor, D.M., Threlfall, G. \& BUCK, A.T. (1966) Stimulation of renal growth in the rat by folic acid. Nature (Lond.), 212, 472.

\title{
Synalbumin insulin antagonism
}

\author{
J. Vallance-Owen \\ Institute of Clinical Science, Grosvenor Road, Belfast 12
}

UsING the technique of the isolated rat diaphragm to measure insulin activity and antagonism, our initial studies on untreated or uncontrolled insulin-requiring diabetic patients showed that their plasma inhibited the activity of insulin in vitro (Vallance-Owen, Hurlock \& Please, 1955). It was then found that this antagonism to insulin was associated with the albumin fraction of the plasma proteins (Vallance-Owen, Dennes \& Campbell, 1958a). Whole plasma from normal subjects and from obese maturity-onset diabetics, who ordinarily do not require insulin therapy, has no measurable insulin antagonism. Nevertheless, when normal plasma is broken down into its various constituents, insulin antagonism can be detected in the 